\title{
A simplified dynamic simulation model (prototype) for a stand-alone Polymer Electrolyte Membrane (PEM) fuel cell stack.
}

\author{
ALI, D.M.
}

2008

(C) 2008 IEEE. Personal use of this material is permitted. Permission from IEEE must be obtained for all other uses, in any current or future media, including reprinting/republishing this material for advertising or promotional purposes, creating new collective works, for resale or redistribution to servers or lists, or reuse of any copyrighted component of this work in other works. 


\title{
A Simplified Dynamic Simulation Model (prototype) for a Stand-Alone Polymer Electrolyte Membrane (PEM) Fuel Cell Stack
}

\author{
Dallia Morsi Ali, MIEE, Chartered Engineer
}

\begin{abstract}
The ever increasing demand for electrical energy and the rise in the electricity prices due to the recent instability of the oil prices in addition to the degrading of the air quality resulting from the emissions of the existing energy conversion devices has intensified research into alternative renewable sources of electrical energy. In this paper a dynamic electrochemical model is developed to simulate a Polymer Electrolyte Membrane fuel cell (PEMFC) system to allow the development and improvement of electrical energy generation systems using this new promising technology. Although other models have been produced but most of these capture the fuel cell (FC) steady state behaviour by estimating its voltage for a particular set of operating conditions. The proposed model allows the incorporation of effects of different dynamic conditions in load current, pressure of input reactant gases, fuel cell operating temperature as well as the mass/heat transfer transient features in the fuel cell body. Its capability of predicting transient dynamics will also prove useful when attempting to develop a control strategy. The proposed model strength is modularizing the fundamental thermalphysical behaviour of a fuel cell and developing a modular block that can be used as a part of any other schematic solution required for fuel cells' study. The developed modular block (prototype) exhibits most of the basic fuel cell properties and incorporates essential physical and electrochemical processes that happen along its operation, allowing its' easy moderation for modelling other fuel cells with different cell parameters and allow investigation of their behaviour for any operating or design configuration. The prototype can be useful in future in studying the integration of fuel cells into distribution power systems. The proposed modular block is implemented in SIMULINK and is verified by generating model results and comparing this to benchmark results for a Ballard NEXA ${ }^{\mathrm{TM}}$ Power module. The proposed model was also compared to another simplified model; sample results for a Ballard V PEMFC were generated for both models indicating that the developed model is more accurate in simulating the fuel cell especially at high operating current densities.
\end{abstract}

KEYWORDS: Renewable Energy, Clean Environment, Fuel cells, Mathematical modelling, Block Simulation.

\section{INTRODUCTION}

Most of the world's $115 \mathrm{GW}$ p.a. power consumption is still generated from the combustion of fossil fuels. This technology, despite of its advanced development, is inefficient (max. efficiency about 50\%), lead to a global warming (generate almost $35 \%$ of greenhouse emissions), as well as becoming expensive and insecure (recent instability of the oil prices). Fuel cells [1, 2, and 3] are electrochemical devices that convert the chemical energy of a gaseous fuel directly into electricity, heat and water thereby eliminating pollution. They combine the best features of engines (can operate for as long as fuel is available) and batteries (produce electricity directly from fuel without combustion reducing emissions and noise and increasing efficiency). Two of their major advantages are their ability to provide power and heat at different scales and in location; and their ability to operate on fuels ranging from fossil fuels through biomass based fuels to renewable. PEMFC emerges as one of the most promising for both stationary and automotive applications [4]. They have more advantages like their high power densities, solid electrolyte-long stack life, low corrosion and higher efficiency $\eta$ (average stack $\eta$ is higher than that of Internal Combustion Engine). Different models of PEMFCs are available in literature [4-10] but these are either more suitable for electrochemical purposes rather than electrical engineering [4-7], or presented a very simplified electrical model [8-10] to be used in deriving a control system. Also most of the available models cannot be easily modified to allow investigation of alternative combinations of system design and operating parameters. Also, in power generation systems, the dynamic response is extremely important for the planner especially when there is injection of energy into the grid. Hence, this paper presents a modular design prototype that is easy to modify to allow simulation of different configurations of a PEMFC, reducing the time and cost associated with a parameter investigation and enable investigation of transients. The model can be used as an initial step to prescribe internal design modifications and/or external controller designs to improve its transient behaviour. The proposed model is implemented in MATLAB/SIMULINK $[11,12]$ and was verified by generating sample results for a Ballard NEXA ${ }^{\mathrm{TM}}$ Power module [13]. Results from the verification investigation were compared to benchmark/experimental data indicating that the developed prototype is accurate in simulating a PEM fuel cell and predicting its performance. The proposed model was also compared to a simplified model [8], results generated for a Ballard V PEMFC [14] were compared showing that the proposed model is more accurate in simulating the fuel cell, especially at operating current densities higher than $1 \mathrm{~A} / \mathrm{cm}^{2}$ $\left(1000 \mathrm{~mA} / \mathrm{cm}^{2}\right)$.

\section{The Fuel CELl System}

A fuel cell stack is formed of a number of cells referred as MEA (Membrane-electrode assembly) composed of a membrane (electrolyte) sandwiched between two porous electrodes. The stack' voltage is determined by the number of cells, and current is determined by the active area of the cells. Other parts of a fuel cell system include: pumps and blowers, 
compressors, cooling system, a power conditioning (voltage regulator to make the cell $\mathrm{DC}$ output suitable for connection to an electrical load) and sometimes a DC/AC inverter. A fuel processing system is needed if the fuel cell does not use pure hydrogen. A controller is needed to coordinate the parts of the system. The fuel cell system consists in general of four sections as in Fig.1. To utilize this system a mathematical model, that simulates it, is necessary in order to analyze the system behaviour in different operating conditions.

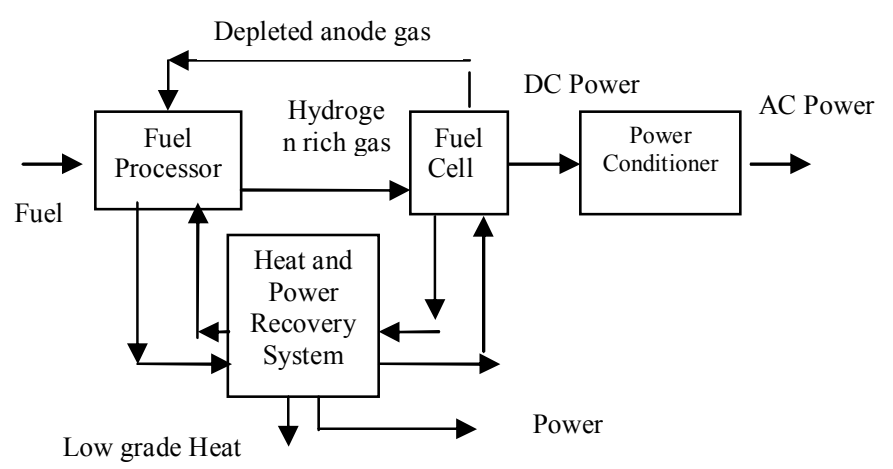

Fig. 1 Block Diagram of a Fuel cell Power Plant

\section{PemfC BAsic Principles ANd Modelling}

A PEMFC depends primarily on a modified polymer membrane (Nafion: as it is mechanically strong, can absorb large quantities of water and is a good proton conductor), coated with highly dispersed catalyst particles (best is platinum although it is the major factor in the cost of PEMFC). The electrodes are usually flat and porous to allow the electrolyte from one side and the gas from the other side to penetrate it. The operating temperature for PEMFC is between 50 and $90{ }^{\circ} \mathrm{C}$.

The electrochemical equations are given by:

At Anode: $\quad \mathrm{H}_{2} \rightarrow 2 \mathrm{H}^{+}+2 \mathrm{e}^{-}$

At Cathode: $2 \mathrm{H}^{+}+2 \mathrm{e}^{-}+1 / 2 \mathrm{O}_{2} \rightarrow \mathrm{H}_{2} \mathrm{O}+$ heat

Overall reaction: $\mathrm{H}_{2}+1 / 2 \mathrm{O}_{2} \rightarrow \mathrm{H}_{2} \mathrm{O}+$ heat

Where: first equation determines the amount of hydrogen needed to be fed to the anode to meet a load, second equation determines amount of oxygen needed to be fed to cathode to maintain reaction, while the third equation determines water produced. The energy released is given by the change in the Gibbs free energy of formation $\Delta \mathrm{G}_{\mathrm{f}}$, which is the difference between the Gibbs free energy of products and that of reactants. It's more convenient to consider these quantities in their per mole form $\left(\mathrm{g}_{\mathrm{f}}\right)$.

$\therefore \Delta \mathrm{g}_{\mathrm{f}}=\mathrm{g}_{\mathrm{f}}$ of products $-\mathrm{g}_{\mathrm{f}}$ of reactants

$\therefore \Delta \mathrm{g}_{\mathrm{f}}=\left(\mathrm{g}_{\mathrm{f}}\right)_{\mathrm{H} 2 \mathrm{O}}-\left(\mathrm{g}_{\mathrm{f}}\right)_{\mathrm{H} 2}-1 / 2\left(\mathrm{~g}_{\mathrm{f}}\right)_{\mathrm{O} 2}$

Gibbs free energy of formation is not constant; it changes with temperature and state (liquid or gas) as in table 1.
TABLE 1: $\Delta \mathrm{g}_{\mathrm{F}}$ FOR THE REACTION $\left(\mathrm{H}_{2}+1 / 2 \mathrm{O}_{2} \rightarrow \mathrm{H}_{2} \mathrm{O}\right)$ AT VARIOUS TEMPERATURES; -VE SIGN MEANS THAT ENERGY IS RELEASED:

\begin{tabular}{|c|c|c|}
\hline Form of water product & $\begin{array}{c}\text { Temperature } \\
\left({ }^{\circ} \mathrm{C}\right)\end{array}$ & $\begin{array}{c}\Delta \mathrm{g}_{\mathrm{f}} \\
\left(\mathrm{kJmol}^{-1}\right)\end{array}$ \\
\hline Liquid & 25 & -237.2 \\
Liquid & 80 & -228.2 \\
Gas & 80 & -226.1 \\
Gas & 100 & -225.2 \\
Gas & 200 & -220.4 \\
Gas & 400 & -210.3 \\
Gas & 600 & -199.6 \\
Gas & 800 & -188.6 \\
Gas & 1000 & -177.4 \\
\hline
\end{tabular}

Modelling of a PEMFC:

\section{A. Anode and Cathode (Reactants) flow Models:}

In these models the dynamically varying pressure of the reactant gas flows (hydrogen and air) are calculated.

To calculate the $\mathrm{O}_{2}$ usage rate:

We know from the basic reaction of fuel cell that 4 electrons are transferred for each mole of oxygen,

$\therefore$ Charge $=4 \mathrm{~F} \mathrm{X}$ amount of oxygen

$\therefore$ Oxygen usage $($ rate $)=\mathrm{I} / 4 \mathrm{~F}$ moles $/ \mathrm{s}$

Where: F: Faraday constant or the charge on one mole of electrons $=96.485 \mathrm{C}$

For a stack of $(\mathrm{N})$ cells:

Oxygen usage $=\mathrm{IN} / 4 \mathrm{~F}$ moles $/ \mathrm{s}$

Or, since $\mathrm{P}=\mathrm{V}_{\mathrm{FC}} \times \mathrm{I} \times \mathrm{N}$, then $\mathrm{I}=\mathrm{P} / \mathrm{NV}_{\mathrm{FC}}$, where $\mathrm{P}$ is the fuel cell power, $\mathrm{V}_{\mathrm{FC}}$ is voltage of each cell.

$\therefore$ Oxygen usage $=\mathrm{P} / 4 \mathrm{~F} \mathrm{~V}_{\mathrm{FC}}$ moles $/ \mathrm{s}$

From the molar mass of $\mathrm{O}_{2}$

$\therefore$ Oxygen usage $=8.29 * 10^{-8} *\left(\mathrm{P} / \mathrm{V}_{\mathrm{FC}}\right) \mathrm{Kg} / \mathrm{s}$

However the molar proportion of oxygen in air is 0.21 ; $\therefore$ Air usage $=3.57 * 10^{-7} *\left(\mathrm{P} / \mathrm{V}_{\mathrm{FC}}\right) \mathrm{Kg} / \mathrm{s}$

To calculate the $\mathrm{H}_{2}$ usage rate:

Similarly, from the basic reaction of fuel cell 2 electrons are transferred for each mole of hydrogen, so:

Charge $=2 \mathrm{~F}^{*}$ amount of hydrogen

$\therefore$ Hydrogen usage $=\mathrm{I} / 2 \mathrm{~F}$ moles $/ \mathrm{s}$

Or, Hydrogen usage $=\mathrm{P} / 2 \mathrm{~F} \mathrm{~V} \mathrm{~V}_{\mathrm{FC}}$ moles $/ \mathrm{s}$

The molar mass of $\mathrm{H}_{2}$ is $2.02 * 10^{-3} \mathrm{~kg} / \mathrm{mol}$

$\therefore$ Hydrogen usage $=1.05 * 10^{-8} *\left(\mathrm{P} / \mathrm{V}_{\mathrm{FC}}\right) \mathrm{Kg} / \mathrm{s}$

The $\mathrm{H}_{2}$ usage rate is useful to know the electrical energy that could be produced from a given mass or volume of hydrogen [Specific enthalpy $(\mathrm{HHV})=39.7 \mathrm{kWh} / \mathrm{kg}$ ]

\section{B. Membrane Hydration Model:}

This represents the process of water transfer across the membrane. Dry membranes reduce proton conductivity and flooded ones block the pores in the electrodes leading to high voltage losses. Ideally, air (oxygen) blown over the cathode diffuse water from the cathode to the anode and throughout electrolyte and dry out any excess water providing a suitable state of hydration, but perturbations can happen. Thus an adjustable parameter $\psi[7$ and 8$]$, that is influenced by membrane preparation procedure and relative humidity; will be included in the proposed model.

$\psi=14$ under ideal condition of $100 \%$ relative humidity. 
$\psi=22$ or 23 under oversaturated conditions.

\section{Stack Voltage Model:}

The typical electrical characteristic of a fuel cell is normally given in the form of a polarization curve, which is a plot of the cell voltage versus cell current density (current/unit cell active area). The difference between actual voltage $V_{\text {F.C }} \&$ ideal voltage of a fuel cell $\mathrm{E}_{\mathrm{Nernst}}$ represents the losses in the cell. As more current is drawn the voltage decreases (due to the FC electrical resistance, inefficient reactant gas transport \& slow reaction). As low voltage indicates low efficiency of the FC, then low load operation is preferred. Notice that since Gibbs free energy of formation changes with temperature \& state, thus the polarization curve varies with different operating conditions as different temperatures, reactant partial pressures and membrane humidity. Therefore, the voltage model should calculate the stack voltage as a function of stack current, reactant partial pressures, cell temperature, and membrane humidity using a combination of physical and empirical relationships. The $\mathrm{o} / \mathrm{p}$ voltage for a PEMFC is basically defined by $[7,8]$ :

$\mathrm{V}_{\mathrm{F} . \mathrm{C}}=\mathrm{N}\left[\mathrm{E}_{\mathrm{Nernst}}-\mathrm{L}\right]$

Where:

$\mathrm{V}_{\mathrm{F} . \mathrm{C}}=$ Stack o/p voltage.

$\mathrm{N}=$ Number of cells forming the stack.

$\mathrm{E}_{\text {Nernst }}=$ Cell potential obtained in an open-circuit thermodynamic balance (no load).

$\mathrm{L}=$ Voltage losses $=\Delta \mathrm{V}_{\text {activation }}+\Delta \mathrm{V}_{\text {ohmic }}+\Delta \mathrm{V}_{\text {conc }}$

- To find $E_{\text {Nernst }}$ :

As it was shown before for each mole of hydrogen 2 electrons

flow, thus the flowing charge is:

Charge $=-2 \mathrm{~F}$ coulombs

Electrical work done $=$ charge $\times$ voltage

$\therefore \Delta \mathrm{g}_{\mathrm{f}}=-2 \mathrm{FE}$ joules

$\therefore \mathrm{E}=-\Delta \mathrm{g}_{\mathrm{f}} / 2 \mathrm{~F}$

Where: $\mathrm{E}$ is the maximum electromotive force or reversible produced open circuit voltage of fuel cell at standard temperature $25^{\circ} \mathrm{C}$.

$\Delta \mathrm{g}$ f: change in Gibbs free energy $(\mathrm{J} / \mathrm{mol})$, which is the available energy to do external work.

To obtain $\mathrm{E}_{\text {Nernst }}$ an extra term is added to take into account changes in temperature with respect to standard reference temperature $25^{\circ} \mathrm{C}$.

$\therefore \mathrm{E}_{\text {Nernst }}=-\Delta \mathrm{g}_{\mathrm{f}} / 2 \mathrm{~F}+\Delta \mathrm{S} / 2 \mathrm{~F}\left(\mathrm{~T}-\mathrm{T}_{\text {ref }}\right)$

Where: $\Delta \mathrm{S}$ : Change of the entropy $(\mathrm{J} / \mathrm{mol})$

$$
\Delta \mathrm{g}_{\mathrm{f}}=\left(\mathrm{g}_{\mathrm{f}}\right)_{\mathrm{H} 2 \mathrm{O}}-\left(\mathrm{g}_{\mathrm{f}}\right)_{\mathrm{H} 2}-1 / 2\left(\mathrm{~g}_{\mathrm{f}}\right)_{\mathrm{O} 2}
$$

As the Gibbs free energy changes with reactant pressure and concentration; Thus:

$$
\begin{aligned}
& \Delta \mathrm{g}_{\mathrm{f}}=\Delta \mathrm{g}_{\mathrm{fo}}+\mathrm{RT} \ln \frac{\left[\mathrm{P}_{\mathrm{H} 2} .\left(\mathrm{P}_{\mathrm{O}}\right)^{1 / 2}\right]}{\mathrm{P}_{\mathrm{H} 2 \mathrm{O}}} \\
& \therefore \mathrm{E}=\mathrm{E}_{\mathrm{O}}+\frac{\mathrm{RT}}{2 \mathrm{~F}} \frac{\left[\ln \frac{\left.\mathrm{P}_{\mathrm{H} 2} \cdot\left(\mathrm{P}_{\mathrm{O} 2}\right)^{1 / 2}\right]}{\mathrm{P}_{\mathrm{H} 2 \mathrm{O}}}\right.}{}
\end{aligned}
$$

Where: $\mathrm{E}_{\mathrm{o}}$ is the cell EMF at standard pressure.

R: Universal gas constant $=8.3145 \mathrm{~J} / \mathrm{kg} . \mathrm{K}$

$\mathrm{T}$ : Fuel cell temperature in $\mathrm{K}$
$\mathrm{P}_{\mathrm{H} 2}, \mathrm{P}_{\mathrm{O} 2}, \mathrm{P}_{\mathrm{H} 2 \mathrm{O}}$ : Partial pressures of hydrogen, oxygen and water.

From equations (3), (4) and by substituting with the known values of the constants and the reference temperature, we obtain the final equation:

$\mathrm{E}_{\text {Nernst }}=1.229-0.85 * 10^{-3} *(\mathrm{~T}-298.15)+4.3085 * 10^{-5} * \mathrm{~T} *$ $\left[\ln \left(\mathrm{P}_{\mathrm{H} 2}\right)+1 / 2 \ln \left(\mathrm{P}_{\mathrm{O} 2}\right)\right]$

\section{- $\quad$ To find the losses $L$ :}

This is divided to activation losses, crossover losses, ohmic losses and concentration losses [7].

1. Activation losses:

This is due to slowness of reactions taking place in the cell. A proportion of the generated voltage is lost in driving the chemical reaction that transfers electrons to or from the electrode.

$$
\begin{aligned}
& \therefore \Delta \mathrm{V}_{\text {act }}=\mathrm{A} \ln (\mathrm{i} / \mathrm{b}) \\
& \left.\mathrm{A}=\mathrm{A}_{\mathrm{a}}+\mathrm{A}_{\mathrm{c}} ; \text { and } \mathrm{b}=\mathrm{i}_{\mathrm{oa}}{ }^{(\mathrm{Aa} / \mathrm{A}}\right)+\mathrm{i}_{\mathrm{oc}}(\mathrm{Ac} / \mathrm{A})
\end{aligned}
$$

Where A (Tafel slope) is a constant in volts and $b$ is a constant in amperes. $A$ is higher for a slow reaction, and $i_{o}$ is higher for a fast reaction, a higher $i_{0}$ will reduce the activation losses and improve the fuel cell performance.

2. Fuel crossover and internal currents:

This energy loss results from the waste of fuel passing through the electrolyte (fuel crossover), as well as some electron conduction through the electrolyte (electrolyte should only transport ions), resulting in a noticeable voltage drop (added to the activation losses). Thus the final Cell activation losses become:

$$
\Delta \mathrm{V}_{\text {act }}=\mathrm{A} \ln \left[\left(\mathrm{i}+\mathrm{i}_{\mathrm{n}}\right) / \mathrm{i}_{\mathrm{o}}\right]
$$

Where: $i_{n}$ is the internal and fuel crossover equivalent current density.

3. Ohmic losses or resistive losses:

This is due to either internal current losses caused by the leakage of some electrons passing through the membrane instead of being utilized, or due to resistive losses caused by electrons flow through the resistance of the whole electric circuit (hydrated membrane reduces ohmic losses). It is proportional to current density.

$$
\Delta \mathrm{V}_{\text {ohm }}=\text { ir }
$$

Where $\mathrm{r}$ : is the area-specific resistance.

4. Mass transport or Concentration losses:

This is due to the change in concentration of reactants at the surface of the electrodes as the fuel is used causing reduction in the partial pressure of reactants, resulting in a reduction in voltage given by:

$\Delta \mathrm{V}_{\text {trans }}=-\mathrm{RT} / \mathrm{n}^{\prime} \mathrm{F} \cdot \ln \left(1-\mathrm{i} / \mathrm{i}_{1}\right)$

Where: $\mathrm{n}$ ' differs for different reactants (it is 2 for hydrogen and 4 for Oxygen).

Or by another approach [8] that is entirely empirical and has become more favoured lately, because it gives same results, provided constants $\mathrm{m}$ and $\mathrm{n}$ are chosen properly:

$\Delta \mathrm{V}_{\text {trans }}=-\mathrm{m} \exp (\mathrm{ni})$

The value of $\mathrm{m}$ will typically be about $3 \times 10^{-5} \mathrm{~V}$, and $\mathrm{n}$ about $8 \times 10^{-3} \mathrm{~cm}^{2} / \mathrm{mA}$.

Combining all losses, the cell voltage becomes: 
$\mathrm{V}=\mathrm{E}-\Delta \mathrm{V}_{\text {ohm }}-\Delta \mathrm{V}_{\text {act }}-\Delta \mathrm{V}_{\text {trans }}$

$\therefore \mathrm{V}=\mathrm{E}-\mathrm{i} \cdot \mathrm{r}-\mathrm{A} \cdot \ln \left[\left(\mathrm{i}+\mathrm{i}_{\mathrm{n}}\right) / \mathrm{i}_{\mathrm{o}}\right]+\mathrm{m} \cdot \exp (\mathrm{ni})$

Where: $\mathrm{E}$ : is the reversible open circuit voltage (OCV) given by equation (2).

Equation (11) is often simplified in a practical way as the crossover current $\mathrm{i}_{\mathrm{n}}$ is usually very small.

$\therefore \mathrm{V}=\mathrm{E}-\mathrm{ir}-\mathrm{A} \ln \left(\mathrm{i} / \mathrm{i}_{\mathrm{o}}\right)+\mathrm{m} \exp (\mathrm{ni})$

$\mathrm{V}=\mathrm{E}-\mathrm{ir}-\left(\mathrm{A} \ln (\mathrm{i})-\mathrm{A} \ln \left(\mathrm{i}_{\mathrm{o}}\right)\right)+\mathrm{m} \exp (\mathrm{ni})$

Put constants together, so: $E_{o c}=E+A \ln \left(i_{o}\right)$

$\therefore \mathrm{V}=\mathrm{E}_{\mathrm{oc}}-\mathrm{ir}-\mathrm{A} \ln (\mathrm{i})+\operatorname{mexp}(\mathrm{ni})$

This simplified emperical model [2] was checked here by developing a SIMULINK [9] modular block for it. Example values of the used constants are given by table 2 . Results obtained in Fig. 2 shows that this model is only accurate in simulating the fuel cell at operating current densities up till 1 $\mathrm{A} / \mathrm{cm}^{2}$ but as the current density gets higher the polarization curve starts to be unreasonable.

TABLE 2: EXAMPLE CONSTANTS FOR EQUATION 14

\begin{tabular}{|c|c|}
\hline Constant & Ballard Mark V PEMFC at $70^{\circ} \mathrm{C}$ \\
\hline $\mathrm{E}_{\mathrm{oc}}(\mathrm{V})$ & 1.031 \\
$\mathrm{r}\left(\mathrm{k} \Omega \mathrm{cm}^{2}\right)$ & $2.45 \times 10^{-4}$ \\
$\mathrm{~A}(\mathrm{~V})$ & 0.03 \\
$\mathrm{~m}(\mathrm{~V})$ & $2.11 \times 10^{-5}$ \\
$\mathrm{n}\left(\mathrm{cm}^{2} / \mathrm{mA}\right)$ & $8 \times 10^{-3}$ \\
\hline
\end{tabular}

Comparison between the proposed fuel cell model and the simplified emperical model polarization curves

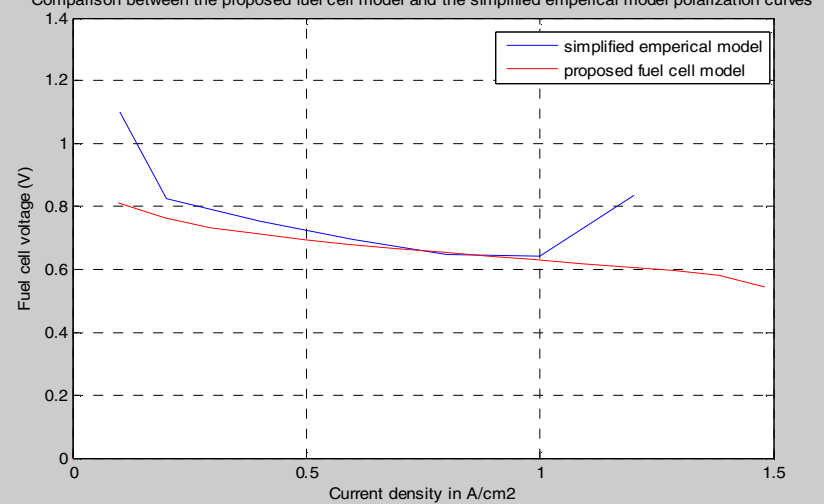

Fig. 2: Resulting Polarization Curve for a fuel cell on using the proposed fuel cell model, compared to that obtained on using simplified model (current density up to $1500 \mathrm{~mA} / \mathrm{cm}^{2}$ or $1.5 \mathrm{~A} / \mathrm{cm}^{2}$ )

\section{Proposed Model:}

A more exact (non-simplified) model is proposed here, in which equation (5) is used to obtain the Cell Reversible Voltage $\mathrm{E}_{\text {Nernst }}$ taking into account changes in temperature with respect to the standard reference temperature $[7,8]$. Then all the voltage losses are considered using the following equations:

\section{Activation Losses:}

The activation voltage drop, including both anode and cathode, can be calculated using $[5,7]$ :

$\Delta \mathrm{V}_{\mathrm{act}}=-\left[\xi_{1}+\xi_{2} * \mathrm{~T}+\xi_{3} * \mathrm{~T} * \ln \left(\mathrm{C}_{\mathrm{O} 2}\right)+\xi_{4} * \mathrm{~T} * \ln \left(\mathrm{i}_{\mathrm{FC}}\right)\right]$

Where: $\mathrm{i}_{\mathrm{FC}}$ : is the cell operating current in (A).

$\mathrm{T}$ : cell operating temperature in Kelvin $(\mathrm{K})$. $\xi$ : parametric coefficients for each cell, whose values are defined based on theoretical equations with kinetic, thermodynamic, and electrochemical foundations [5].

$\mathrm{C}_{\mathrm{O} 2}$ : is the concentration of oxygen in the catalytic interface of the cathode $\left(\mathrm{mol} / \mathrm{cm}^{3}\right)$, and determined by: $\mathrm{C}_{\mathrm{O} 2}=\mathrm{P}_{\mathrm{O} 2} /(5.08$ $\left.* 10^{6} * \mathrm{e}^{(-498 / \mathrm{T})}\right)$

2. Ohmic Losses:

It will be obtained using the general expression for resistance including all membrane parameters.

$\mathrm{R}_{\mathrm{M}}=\rho_{\mathrm{M}} * \mathrm{~L} / \mathrm{A}$

Where: L: thickness of the membrane in $\mathrm{cm}$

A: cell active area in $\mathrm{cm}^{2}$.

$\rho_{\mathrm{M}}$ is the specific resistivity of the membrane to the electron flow $(\Omega . \mathrm{cm})$ given by [5]:

$\rho_{\mathrm{M}}=\left(181.6 *\left[1+0.03 *\left(\mathrm{i}_{\mathrm{FC}} / \mathrm{A}\right)+0.062 *(\mathrm{~T} / 303)^{2} *\left(\mathrm{i}_{\mathrm{FC}}\right.\right.\right.$ $\left.\left./ \mathrm{A})^{2.5}\right]\right) /\left(\left[\psi-0.634-3 *\left(\mathrm{i}_{\mathrm{FC}} / \mathrm{A}\right)\right] * \exp [4.18 *((\mathrm{~T}-\right.$ 303)/T)] )

Where, the exponential term is the temperature correction if the cell is not operating at $30^{\circ} \mathrm{C}(303 \mathrm{~K})$.

$\Psi=14$ (ideal condition), 23 (oversaturated).

Then the ohmic voltage drop is determined by:

$\Delta \mathrm{V}_{\mathrm{ohm}}=\mathrm{i}_{\mathrm{FC}} *\left(\mathrm{R}_{\mathrm{M}}+\mathrm{R}_{\mathrm{C}}\right)$

Where: $R_{C}$ is resistance to protons transfer through the membrane, and usually considered constant.

3. Concentration Losses:

This will be determined by:

$\Delta \mathrm{V}_{\text {con }}=-\mathrm{B}^{*} \ln \left(1-\mathrm{j} / \mathrm{j}_{\max }\right)$

Where: $B$ : is a parametric coefficient in volts, which depends on the cell and its operation state.

$\mathrm{j}=\mathrm{i}_{\mathrm{FC}} / \mathrm{A}$ : actual current density of the cell $\left(\mathrm{A} / \mathrm{cm}^{2}\right)$.

$\mathrm{j}_{\max }$ : is the maximum current density at which the fuel is used at same rate of the maximum supply speed, it is in range of $\left(500-1500 \mathrm{~mA} / \mathrm{cm}^{2}\right)$.

The above equations were all implemented in MATLAB/Simulink [9] software to develop a prototype for simulating the fuel cell. The proposed model prototype was then validated using the same Ballard V PEMFC. Parameters used for this simulation is given in table 3 .

TABLE 3: PARAMETERS OF THE USED BALLARD MARK V FUEL

\begin{tabular}{|l|l|l|l|}
\multicolumn{5}{|c|}{ CELL } \\
\hline Parameter & Value & Parameter & Value \\
\hline $\mathrm{T}$ & $70{ }^{\circ} \mathrm{C}(343 \mathrm{~K})$ & $\xi_{1}$ & -0.948 \\
\hline $\mathrm{A}$ & $50.6 \mathrm{~cm}^{2}$ & $\xi_{2}$ & $\begin{array}{l}0.00286+0.0002 * \\
\ln (\mathrm{A})+\left(4.3 * 10^{-5}\right)^{*} \\
\ln \mathrm{C}_{\mathrm{H} 2}\end{array}$ \\
& & & $7.6^{*} 10^{-5}$ \\
\hline $\mathrm{L}$ & $178^{*} 10^{-4} \mathrm{~cm}$ & $\xi_{3}$ & $-1.93 * 10^{-4}$ \\
\hline $\mathrm{P}_{\mathrm{H} 2}$ & $1 \mathrm{~atm}$. & $\xi_{4}$ & 23 \\
\hline $\mathrm{P}_{\mathrm{O} 2}$ & $1 \mathrm{~atm}$. & $\Psi$ & $1.5 \mathrm{~A} / \mathrm{cm}^{2}$ \\
\hline $\mathrm{B}$ & $0.016 \mathrm{~V}$ & $\mathrm{j}_{\max }$ & $0.0012 \mathrm{~A} / \mathrm{cm}^{2}$ \\
\hline $\mathrm{R}_{\mathrm{C}}$ & $0.0003 \Omega$ & $\mathrm{j}_{\mathrm{n}}$ & $\mathrm{c}$ \\
\hline
\end{tabular}

Results of the proposed model are given in figure 2, compared to that obtained using simplified model; confirm that the proposed model prototype is more accurate in simulating the fuel cell especially at higher current densities above $1 \mathrm{~A} / \mathrm{cm}^{2}$.

The operating temperature and the fuel/air flow are the two important dynamic properties of the fuel cell. Thus it will be demonstrated here how they will affect the fuel cell voltage. 
The effect of change of cell temperature on output voltage is shown in Fig. 3. A rise of only $20^{\circ} \mathrm{C}$ results in a voltage rise.

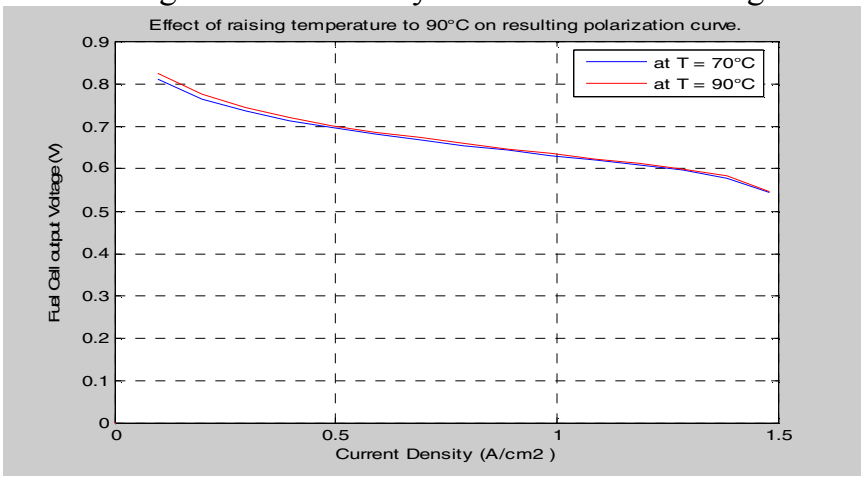

Fig. 3 Effect of temperature change on the output fuel cell voltage

The effect of the fuel/air flow (oxygen \& hydrogen input pressures) was also considered in the proposed model prototype. An increase in fuel/air input pressure from the atmospheric pressure was found to raise the exchange current density, which has an apparent effect of raising the open circuit voltage as can be seen in Fig. 4.

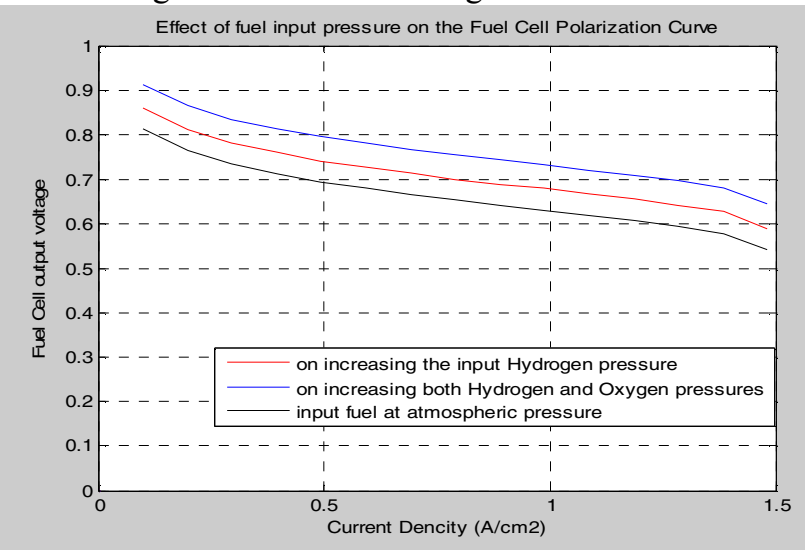

Fig. 4: Polarization Curves shows the resulting boost in fuel cell voltage when operating at a higher hydrogen and oxygen pressures

The total number of cells in a stack affects the resulting stack voltage as can be seen in Fig. 5. On using 1000 cells the stack voltage is raised to about $800 \mathrm{~V}$ at normal atmospheric pressure and low current density.

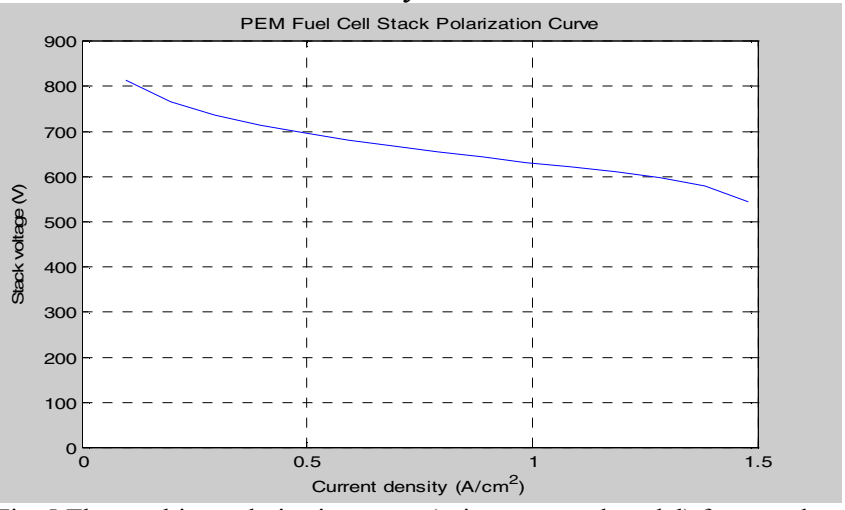

Fig. 5 The resulting polarization curve (using proposed model) for a stack PEMFC system made of 1000 cells
Correlation of the proposed model with experimental investigation for the lab Ballard NEXA ${ }^{\mathrm{TM}}$ Power module shown in Fig.6 is also performed. Comparisons between the proposed model predicted results and the benchmark/experimental results are given in Figures $7 \& 8$ consequently confirming their agreement.

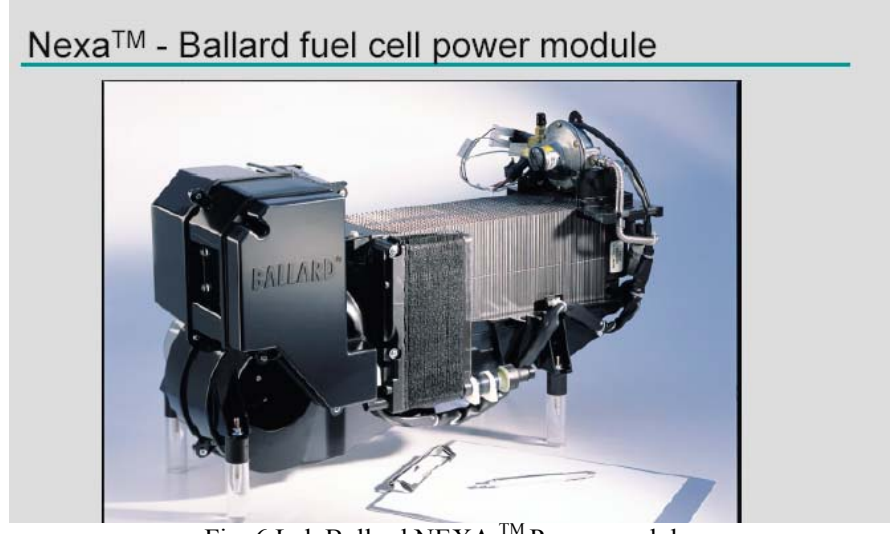

Fig. 6 Lab Ballard NEXA ${ }^{\mathrm{TM}}$ Power module

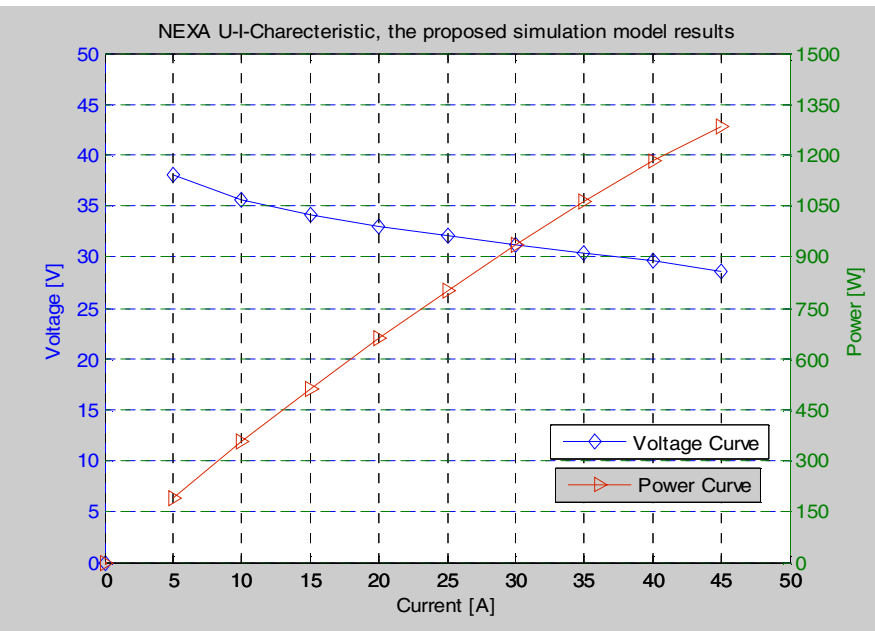

Fig. 7 Proposed Model resulting Polarization and Power Curves for the lab Ballard NEXA ${ }^{\mathrm{TM}}$ Power module

\section{NEXA U-I-Characteristic}

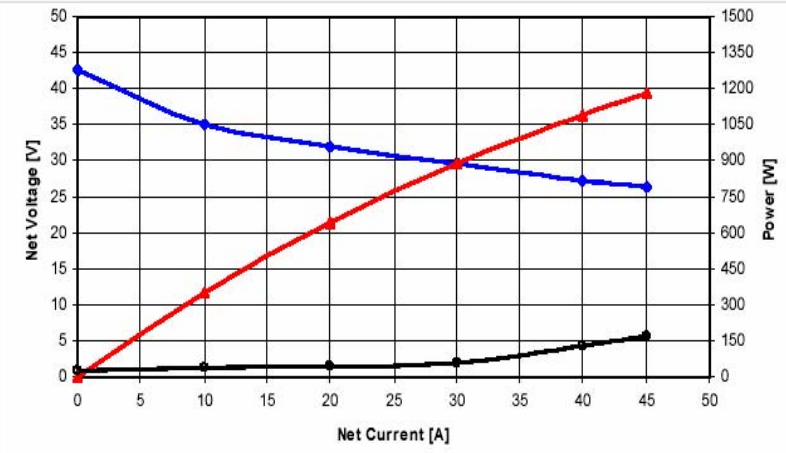

Fig. 8 Benchmark/experimental Polarization and Power Curves for the lab Ballard NEXA ${ }^{\mathrm{TM}}$ Power module 


\section{STACK EFFICIENCY}

Efficiency $\eta=$ electrical energy produced per mole of fuel/- $\Delta h$ Where: $\Delta \mathrm{h}_{\mathrm{f}},=-241.83 \mathrm{~kJ} / \mathrm{mol}$ if product is steam and is $285.84 \mathrm{~kJ} / \mathrm{mol}$ if product water. The maximum possible efficiency (thermodynamic efficiency) is when the electrical energy is equal to change in Gibbs free energy.

$\therefore$ Maximum efficiency possible $=\Delta \mathrm{g}_{\mathrm{f}} / \Delta \mathrm{h}_{\mathrm{f}} \times 100 \%$

The output voltage of a fuel cell $\mathbf{V}_{\mathbf{c}}$ is then related to efficiency by adapting equation (2). If all the energy from the hydrogen fuel is transformed to electrical energy, then: $\mathrm{E}=-\Delta \mathrm{h}$ ${ }_{f} / 2 \mathrm{~F}=(1.48)$ at $\mathrm{HHV}$ and (1.25) at LHV

Therefore actual efficiency (output/input) is then:

$\eta=\left(\mathrm{V}_{\mathrm{c}} / 1.48\right) \times 100 \% \quad$ (with reference to HHV)

$\eta=\left(\mathrm{V}_{\mathrm{c}} / 1.25\right) \times 100 \% \quad$ (with reference to LHV)

However, in practice not all the fed fuel is used. Thus a fuel utilization coefficient can be defined as:

$\mu_{\mathrm{f}}=\quad$ mass of cell's reacted fuel

mass of input fuel to cell

$\eta=\mu_{\mathrm{f}} \mathrm{V}_{\mathrm{c}} / 1.48100 \% \quad$ (with reference to HHV)

$\eta=\mu_{\mathrm{f}} \mathrm{V}_{\mathrm{c}} / 1.25100 \% \quad$ (with reference to LHV)

This equation (HHV) is implemented in both the simplified and proposed models' prototypes to obtain the efficiency curves. Resulting efficiency curves from both models for the used Ballard V PEMFC are compared in Fig. 9.

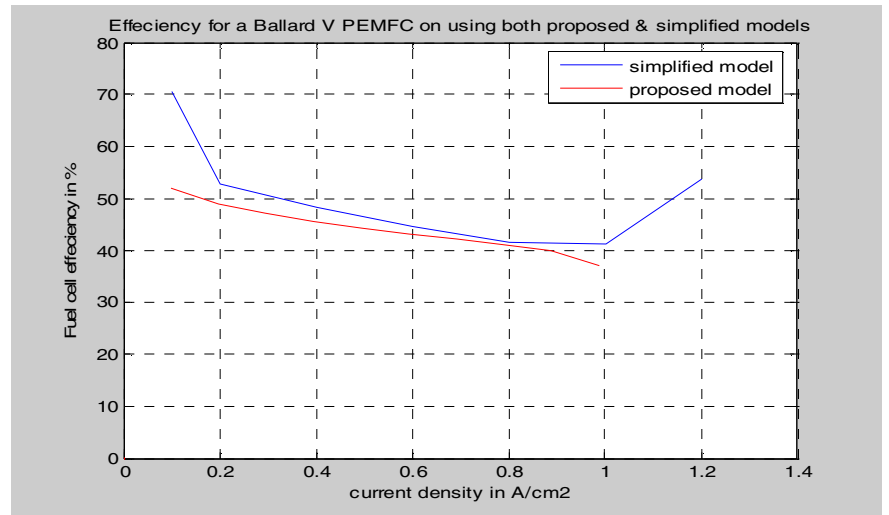

Fig. 9 Efficiency Curve using both proposed and simplified empirical models prototype (reference to $\mathrm{HHV}$ )

\section{CONCLUSION}

Two prototypes for modelling the fuel cell, by using both the simplified and the proposed mathematical models respectively, were developed tested and compared. Although the prototype produced using the simplified model gave reasonable results, the proposed model prototype was found to give better results especially at current densities greater than $1 \mathrm{~A} / \mathrm{cm}^{2}$. A further advantage of the proposed prototype is that it can be changed easily because it is built out of different autonomous operating blocks. The proposed prototype can be useful in many applications in future such as:

1. Estimate the performance of a specific fuel cell system and investigate its behaviour as an initial step toward investigating internal design modifications and/or external controller designs to improve its transient response.
2. Estimate the performance of a specific application that uses a fuel cell system, for example the integration of a fuel cell into a power system.

\section{REFERENCES}

1. http://www.fuelcellknowledge.org/

2. http://www.fuelcelltoday.com/

3. James Larminie and Andrew Dicks: 'Fuel Cell Systems Explained, Second Edition,' John Willey \& Sons Ltd; 2003.

4. Boettner DD., Paganelli G., Guezennec YG., Rizzoni G., Moran MJ.: 'Proton exchange membrane fuel cell system model for automotive vehicle simulation and control', Journal of Energy Resources and Technology 2002; 124 (20):20-7.

5. Denver Cheddie, Norman Munroe: 'Parametric model of an intermediate temperature PEMFC', Journal of Power Sources, DTD 5, pp 1-10, 2005.

6. Chu, D. and Jiang, R.: 'Performance of polymer electrolyte membrane fuel cell (PEMFC) stacks-part I. Evaluation and simulation of an airbreathing PEMFC stack', J. Power Sources, vol.83, pp. 128-133, 1999.

7. Mann R. F., Amphlett J. C., Hooper M.A. I., Jensen H. M, Peppley B. A., and Roberge P. R.: 'Development and Application of a generalized steady-state electrochemical model for a PEM fuel cell,' J. Power Sources, vol.86, 2000, pp.173-180.

8. Lee J. H., Lalk T. R.: 'Modelling Fuel Cell Stack Systems,' Journal of Power Sources 73 (1998), pp $229-241$.

9. Rowe, A. and Li, X.: 'Mathematical modelling of proton exchange membrane fuel cells', Journal of Power Sources 2001, 102, pp. 82-96.

10. Lu-Ying Chiu, Bill Diong, and Randall S. Gemmen: 'An Improved Small-Signal Model of Dynamic Behaviour of PEM Fuel Cells,' IEEE Transactions on Industry Applications, Vol.40, July/August 2004.

11. William J. Palm: 'Introduction to Mat lab 7 for Engineers,' McGraw Hill.

12. Simulink is a product of the Math-works. (http://www.mathworks.com/).

13. 'Data sheet of a $1.2 \mathrm{~kW}$ Ballard $\mathrm{NEXA}^{\mathrm{TM}}$ Power Module', Ballard Power Systems Inc., 2004 Ballard Power Systems Corp. AN2001-04.

14. 'Data sheet of one single cell model Ballard Mark V fuel cell,' BCS Technologies, Englewood, CO, 2001. 